\title{
A STUDY OF THE MARKET SHARE OF CREDIT PORTFOLIO THROUGH A NEURAL NETWORK
}

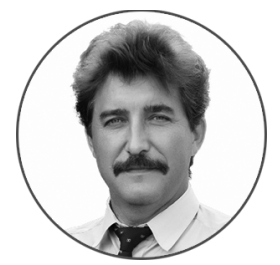

\author{
Nikolai I. LOMAKIN \\ Volgograd State Technical University, Volgograd, Russian Federation \\ tel9033176642@yahoo.com \\ Corresponding author
}

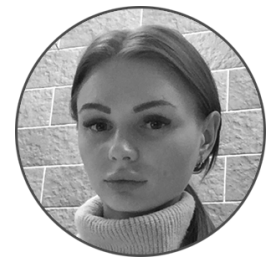

Yuliya V. FEMELIDI

Volgograd State Technical University, Volgograd, Russian Federation yul010294@gmail.com

\section{Article history:}

Received 17 May 2017

Received in revised form 30 August 2017

Accepted 21 September 2017

Translated 22 February 2018

Available online 27 March 2018

JEL classification: $\mathrm{C} 45, \mathrm{C} 58, \mathrm{C} 81$

Keywords: market share, portfolio,

\begin{abstract}
Importance The article studies the evolution of credit portfolios of the Russian banks during the analyzable using the self-organizing map (SOM).

Objectives The article aims to prove or refute the hypothesis that by using a neural network, i.e. self-organizing map, it is possible to predict changes in the market share of bank's credit portfolio.

Methods For the study, we used the self-organizing map.

Results We have developed and now present a neural network model that helps predict the market share of a credit portfolio in a changing market under economic uncertainty environment.

Conclusions and Relevance The application of the self-organizing map is important for obtaining some statistical information on commercial banks in the model clusters, as well as for forecasting the market share of the organization in a changing market environment. The findings can be used in bank marketing to predict
\end{abstract} Kohonen map, neural network, marketing the market share of the bank when the size of its portfolio changes.

policy

@ Publishing house FINANCE and CREDIT, 2017

The editor-in-charge of this article was Irina M. Vechkanova

Authorized translation by Irina M. Vechkanova

In current circumstances, the bank's credit portfolio management determines the effectiveness of strategic marketing in terms of credit risks under the market uncertainty, and competitiveness of the bank, trends in its market share as the portfolio size changes, being a fundamental metric of competitiveness.

${ }^{\dagger}$ For the source article, please refer to: Ломакин Н.И., Фемелиди Ю.В. Исследование рыночной доли кредитного портфеля банка с помощью нейронной сети. Финансовая аналитика: проблемы и решения. 2017. Т. 10, № 11. С. 1220-1233. URL: https://doi.org/10.24891/fa.10.11.1220
The novelty of the research is an attempt to build a mathematical model - the Kohonen map, that would allow to predict the credit portfolio share of a commercial bank.

It is noteworthy that some credit portfolio management (CPM) aspects have not been studied sufficiently as yet, thus raising the practical value of the issue.

As seen in other researches, CPM stands at the crossroads of management, banking, investment, 
lending and marketing. It proves how many aspects this problem involves in case of the market uncertainty.

These aspects can hardly be called understudied. Issues of management, including strategic one, are investigated by such researchers as I. Ansoff, M. Porter, A.J. Strickland et al. [1-3]. Overviewing contemporary Russian and foreign literature, we can point out some researches by Russian and foreign economists.

Scrutinizing what distinguishes effective management of a credit portfolio, T.V. Grebennik focused on the process quality and relevant issues [4, p. 145]. Doing so, she referred to methodological principles of quality, which were found by B.A. Raizberg, L.Sh. Lozovskii, E.B. Starodubtseva'.

The methodology for managing an investment portfolio, to which loans can be easily attributed, is studied in proceedings by H. Markowitz, W. Sharpe, N. Lomakin².

Russian scientists V.K. Silaeva, D.A. Krykhtina view portfolios of banks as a separate item to be managed ${ }^{3}$. The credit portfolio risk, the most critical metric, was examined by A.I. Grishankin [5], V.A. Korotina ${ }^{4}$ et al.

Considering the market uncertainty, it is important to enhance an evaluation of a credit portfolio in a commercial bank. It became the subject of researches by S.N. Yakovenko, A.S. Markelov [6, pp. 596-601].

M.J. Miranda and S. Gonzalez-Vega gained deeper insights into the issue, unraveling the concept of inherent risk and index insurance risks in the appropriate management of an agricultural credit portfolio [7, pp. 399-406]. J. Marshall investigated some

\footnotetext{
${ }^{1}$ Raizberg B.A., Lozovskii L.Sh., Starodubtseva E.B. Sovremennyi ekonomicheskii slovar [Contemporary Dictionary of Economics]. Moscow, INFRA-M Publ., 2005, pp. 150-151.

${ }^{2}$ Lomakin N.I., Krykhtina D.A., Sergienko V. [Criteria to build a bond portfolio of a commercial bank]. Vzaimodeistvie predpriyatii I vuzov nauka, kadry, novye tekhnologii: materialy konferentsii [Proc. Sci. Conf. Interaction of enterprises and universities: Science, talent, new technology]. Volgograd, VolSTU Publ., 2016, pp. 153-158.

${ }^{3}$ Krykhtina D.A., Silaeva V.K. et al. [Assessing the bond portfolio of a commercial bank]. Vzaimodeistvie predpriyatii I vuzov - nauka, kadry, novye tekhnologii: materialy konferentsii [Proc. Sci. Conf. Interaction of enterprises and universities: Science, talent, new technology]. Volgograd, VolSTU Publ., 2016, pp. 163-169.

${ }^{4}$ Korotina V.A., Lomakin N.I., Razumnyi A.S., Biryukov A.R. [Managing the financial risk through neural networks and fuzzy algorithms]. 15-ya nauchnaya konferentsiya prepodavatel'skogo sostava VPI: materialy konferentsii [Proc. Sci. Conf. 15th Conference of Academic Professors of Volgograd Politechnical Institute]. Volgograd, VolSTU Publ., 2016, part 1, pp. 225-227.
}

CPM issues [8, pp. 122-124] and formulated effective management policies through the systems approach to risk assessment.

The scholarly team led by A. Lucas proposed their own analytical view to the credit risk of major corporate bonds and loan portfolios [9, p. 1635].

We should single out A.N. Kadyrov among the Russian scholars dealing with this aspect since he devised a technique for classifying the borrower's risk [10, pp. 46-51]. According to O.N. Maksimova, innovative approaches to competition and marketing are in sync with the current challenges [11, p. 184].

Many scholars discussed similar issues. Such renown scholars as S.L. Brue, J. Keynes, J. Robbins and A. Smith made an invaluable contribution to the theory of competition. For instance, F. Knight presented his classic concept of relationship between risk and uncertainty [12].

Despite giving proper respect to the above researches, we still emphasize that strategic management issues are insufficiently elaborated in relation to credit portfolios through artificial intelligence systems.

Certain authors address the use of neural networks in financial markets. For example, the stock price forecast based on the neural network helped estimate future prices for the asset within a 5-percent error threshold [13]. Neural networks also worked for analyzing the volatile value of IBM in the stock exchange ${ }^{5}$. However, practical processes engender new challenges as all the types of risks grow under the market uncertainty.

As studies show, the recent years have seen a significant reduction in the number of the Russian credit institutions, and this trend gains momentum. The total number of credit institutions fell from 1,311 down to 623 , or by 46.5 percent, within 2001-2017. It is a sign of considerable transformation processes in banking driven by internal and external factors.

Determining aspects of the Russian banking are important to study not only to make forecasts of the nearest and distant future. There is a strong

\footnotetext{
${ }^{5}$ Augustine M.P. An Investigation of Weak Form of the Efficient Market Hypothesis Using Neural Networks: Analyzing IBM Common Stock Price. Nova Southeastern University, 1999.
}

Please cite this article as: Lomakin N.I., Femelidi Yu.V.A Study of the Market Share of Loan Portfolio Through a Neural Network. 
likelihood that there will be less commercial banks left in the market.

Having processed data in a Microsoft Office Excel document, we got a polynomial equation expressing how the quantity of banks varies year by year:

$y=-2.0267 x^{2}-5.762 x+1,346.4$

where $x$ means the period expressed in years.

The accuracy of approximation $R^{2}=0.9825$ signifies that the relationship is strong $\left(R^{2} \geq 0.75\right)$ and the resulting feature (the number of banks) is 98.25-percent dependent on the factorial feature of time.

Using the correlation equation, we can reliably assess the number of banks in the future by the method of extrapolation. Inserting $x=18$ (the following observation goes eighteenth), we arrive at:

$y=-2.0267 \cdot 324-5.762 \cdot 18+1,346.4=586$.

It is very close to factual values, since, as of January 1, 2017, there were 623 banks, while only 567 ones are left as of March 1, 2017.

In practice, the Central Bank of the Russian Federation applies the method of grouping, thus forming six groups by amount of assets (Table 1).

As fewer commercial banks remain operational, it is vital to study trends in the market share of a credit portfolio in order to improve marketing communications.

We obtain input data from the website of the Central Bank of Russia and present them as a graph (Fig. 1).

As the analysis reveals, assets are predominantly concentrated in five banks of the first group (55.8 percent) and 15 banks of the second one (21.2 percent). Such concentration is typical of oligopolies. We got rather curious results by analyzing trends in groups of banks (Fig. 2).

What we also found out was that Top-50 banks demonstrated sustainable development in the analyzable period (first, second, third groups). For example, banks of the first group raised their assets by 10.4 percent, while their loan portfolios increased by 23.9 percent.

Mid-range banks make up an unsustainable group on the rear of Top-200. In this group, assets shrank by 1.6 percent and credit portfolio rose by 13 percent. The fifth and sixth groups represented with a myriad of small banks (423) face the toughest situation. Assets reduced by 21.1 and 60.3 percent respectively. Identical movements are registered in their credit portfolios, 23.9 and 65 percent respectively.

It is reasonable to analyze trends in credit portfolios using the Kohonen Self-Organizing Map (SOM). We randomly pick up banks' indicators within the period from August 1, 2015 through August 1, 2016. We make up a file, which will present factorial features of the neural network:

- bank's portfolio as of August 1, 2016, thousand RUB;

- market share as of August 1, 2016, \%;

- bank's portfolio as of August 1, 2015, thousand RUB;

- market share as of August 1, 2015, \%;

- portfolio changes, thousand RUB;

- portfolio changes, \%.

We introduce input data of 583 banks included into the population (Table 2).

Processed with the mathematical algorithm of the neural network via the Deductor platform developed by Base Group, tabular figures are as follows as given in (Fig. 3).

For example in case of Sberbank, we have the following electronically processed data:

- cell number is 31 ;

- distance to the cell center - 7.029853;

- cluster number - 0;

- distance to the cluster center - 0.0877995946116151 .

To analyze statistical parameters of each commercial bank, we draw upon capabilities of the Deductor software, with the input data being processed through the neural network.

The Kohonen SMO represents a variety of neural network algorithms. What distinguishes this technology is that it implies unsupervised learning. The outcome depends only on the composition of input data. Such neural networks are frequently used to address 
a spectrum of tasks ranging from data analysis to pattern recognition, for example, in finance ${ }^{6}$.

To say it in other words, SOM enables users to project multivariate space into the other of lower dimensionality. When the algorithm is used, initially similar vectors happen to run alongside in the resultant map (Fig. 4).

The cross denotes coordinates of an input vector. Coordinates of the map nodes are colored grey upon their modification. The grid after modification are depicted with dashed lines. In a training set, the maximum error threshold is 0.009 percent, while it is 0.018 percent for the test set. The trained model generates data which reflect the composition and structure of the entire population of banks (Fig. 5).

To modify weight coefficients, the following formula is used:

$W_{i}(t+1)=W_{i}(t)+h c_{i}(t)[x(t)-w(t)] w_{i}(t+1)=$

$=W_{i}(t)+h c_{i}(t)[x(t)-w(t)]$,

where $t$ is the epoch number (discrete time);

$x(t)$ is a vector that is randomly picked up out of the training set during the iteration $t$;

$h(t)$ is the adjacency function of neurons.

Resulting from the processing of input data, the view of clusters reflects a concentration of major banks in the upper right-hand part of the rectangular pictures. The cluster profile shall be pointed out among properties the neural network program infers.

The table is based on a grouping of clusters $0-10$, which includes values (absolute, relative and percentage-oftotal). The program computes the following parameters per each cluster, such as significance, confidence interval and standard error (Fig. 6).

Surveying cluster statistics, we conclude on the extremely uneven distribution of banks, i.e. the principal part of banks - 540 small banks $(92.8$ percent) - are attributed to Cluster 5 , while Cluster 6 is made up of 17 banks (2.9 percent) and onward to Cluster 0 occupied by giant Sberbank ( 0.2 percent) (Table 3).

\footnotetext{
${ }^{6}$ Lomakin N.I., Orlova E.R. et al. Analysis Order Book with a Card of Kohonen. URL: http://conf.ostis.net/images/ 7/77/50._lomakinAnalyOBwCoK.pdf
}

Researchers state that the volume of credit portfolios demonstrates some deviation in different clusters (Fig. 7).

Let us look at credit portfolio trends of iMoneyBank added to Cluster 6 on a random basis.

Throughout the 2015-2016 period, the credit portfolio decreased down to RUB 3,237,447 thousand, or by 12.26 percent. Therefore, the market share of the bank's credit portfolio shrank from 0.0344 down to 0.0314 percent.

As part of operations with the Kohonen SMO, Deductor's what-if function helps assess trends in the market share of iMoneyBank if its portfolio reduces by RUB 452,194 thousand, i.e. keeping the same step as last year. That is, the bank's share will diminish to 0.0284 percent.

As our assessments show, Cluster 6 banks need to have a credit portfolio of at least RUB 800 billion to ensure their sustainable development. Such forecasts are important for competition in order to refine the development strategy.

As of January 1, 2017, the value of iMoneyBank's credit portfolio actually fell by 25.07 percent, i.e. the credit portfolio and the market share decreased to RUB 2,425,668 thousand and 0.0203 percent respectively.

According to researches, the Kohonen SMO facilitates predicting what will happen with the market share of a credit portfolio. Innovative assessment methods provide us with new opportunities. However, to use the opportunities, we need to supplement the model with more factors, thus improving the proposed neural network model [14, p. 197].

Commercial banks may rely on findings of theoretical studies, including the credit risk pattern recognition, to outline their development strategies in current circumstances. For example, the credit portfolio quality can be enhanced through special algorithms, which are validated with certificates of computer program registration ${ }^{7}$.

\footnotetext{
${ }^{7}$ Lomakin N.I., Moskovtsev A.F., Sazonov S.P. Svidetel'stvo o gos. registratsii programmy dlya EVM № 2015660126 ot 22.09.2015 [Certificate of Computer Program № 2015660126 of September 22, 2015. Russian Federation. The neural network mechanism for assessing the risk of corporate bankruptcy of the bank's customer]. Volgograd, VolSTU Publ., 2015; Lomakin N.I., Rybanov A.A., Angel O.V., Litvinov K.V., Popova Ya.A.,
} 
Considering the escalating market uncertainty, banks should put more effort into improving their marketing policy. It shall stipulate a possible response to economic developments driven by modern information technology. As competition gets tougher in banking, the market share is difficult to occupy without advanced financial products.

Referring to the above statements, we can make the following conclusions:

- the use of the Kohonen SMO is critical to obtain certain statistical information on commercial banks;

- neural network algorithms facilitate forecasting the market share in a constantly changing market environment;
- it is important to study the Russian market of banks in current circumstances since an in-depth analysis of a particular commercial banks open possible opportunities for its development;

- the national banking system evolves under certain laws and changing factors, which can be detected and evaluated with the Kohonen SMO;

- neural network helps not only visualize detailed statistical data on each grouping of banks, but also forecast values of a certain parameter.

Tolochko N.I., Goncharova E.V. Svidetel'stvo o gos. registratsii programmy dlya EVM № 2015619932 ot 17.09.2015. RF. Otsenka kreditosposobnosti klientov fizicheskikh lits s pomoshch'yu neiroseti [Certificate of Computer Program Registration № 2015619932 of September 17, 2015. Russian Federation. Evaluating the personal solvency of individuals using a neural network]. Volgograd, VolSTU Publ., 2015.

Please cite this article as: Lomakin N.I., Femelidi Yu.V.A Study of the Market Share of Loan Portfolio Through a Neural Network. 
Table 1

Groups of commercial banks ranked by the Central Bank of the Russian Federation by value of assets (in descending order)

\begin{tabular}{|c|c|c|c|c|c|c|c|c|}
\hline \multirow[t]{2}{*}{ Year } & \multirow{2}{*}{$\begin{array}{l}\text { Indicators, } \\
\text { thousand RUB }\end{array}$} & \multicolumn{6}{|c|}{ Grouping by number of banks } & \multirow[t]{2}{*}{ Total } \\
\hline & & $1-5$ & $6-20$ & $21-50$ & $51-200$ & $201-500$ & $501-623$ & \\
\hline \multirow[t]{2}{*}{2015} & Assets (liabilities) & $40,411,253$ & $15,951,580$ & $8,226,817$ & $7,785,677$ & $2,133,048$ & 332,940 & $74,841,315$ \\
\hline & Loan portfolio & $24,674,904$ & $8,674,414$ & $4,187,901$ & $3,847,660$ & $1,082,698$ & 163,953 & $42,631,529$ \\
\hline \multirow[t]{2}{*}{2016} & Assets (liabilities) & $44,633,141$ & $16,964,047$ & $8,935,107$ & $7,664,417$ & $1,683,255$ & 132,130 & $80,012,097$ \\
\hline & Loan portfolio & $30,580,049$ & $9,465,601$ & $5,140,543$ & $4,348,337$ & 823,601 & 57,396 & $50,415,529$ \\
\hline
\end{tabular}

Source:The Bank of Russia data

Table 2

Loan portfolio and market share trends: a fragment

\begin{tabular}{lllllll}
\hline Bank & $\begin{array}{l}\text { Portfolio } \\
\text { as of August 1, 2016, } \\
\text { thousand RUB }\end{array}$ & $\begin{array}{l}\text { Market } \\
\text { share, \% }\end{array}$ & $\begin{array}{l}\text { Portfolio } \\
\text { as of August 1, 2015, } \\
\text { thousand RUB }\end{array}$ & Market share, \% & $\begin{array}{l}\text { Amount } \\
\text { of change, } \\
\text { thousand RUB }\end{array}$ & $\begin{array}{l}\text { Change (+, -), } \\
\%\end{array}$ \\
\hline Absolut Bank & $46,058,877$ & 0.447 & $33,587,303$ & 0.3129 & $12,471,574$ & +37.13 \\
\hline Avangard & $6,231,216$ & 0.0605 & $8,515,979$ & 0.0793 & $-2,284,763$ & -26.83 \\
\hline Avers & $3,791,341$ & 0.0368 & $3,032,991$ & 0.0283 & 758,350 & +25 \\
\hline Avtogradbank & $1,283,998$ & 0.0125 & $1,490,150$ & 0.0139 & $-206,152$ & -13.83 \\
\hline Avtokreditbank & 105,804 & 0.001 & 87,474 & 0.0008 & 18,330 & +20.95 \\
\hline Avtotorgbank & 574,486 & 0.0056 & $1,319,126$ & 0.0123 & $-744,640$ & -56.45 \\
\hline Agropromkredit & $4,666,521$ & 0.0453 & $6,693,820$ & 0.0624 & $-2,027,299$ & -30.29 \\
\hline Agroros & 394,062 & 0.0038 & 394,214 & 0.0037 & -152 & -0.04 \\
\hline Agrosoyuz & $1,407,510$ & 0.0137 & $1,685,881$ & 0.0157 & $-278,371$ & -16.51 \\
\hline
\end{tabular}

Source : Authoring

Table 3

Parameters of bank factors by cluster

\begin{tabular}{|c|c|c|c|c|c|}
\hline Indicator & Cluster 5 & Cluster 6 & Cluster 4 & Cluster 9 & Cluster 7 \\
\hline The number of banks & 540 & 17 & 9 & 8 & 3 \\
\hline$\%$ of the total & 92.8 & 2.9 & 1.5 & 1.4 & 0.5 \\
\hline Mean & $1,859,610$ & $46,945,422$ & $72,445,287$ & $111,562,226$ & $134,200,806$ \\
\hline Standard deviation & $4,718,922$ & $28,165,987$ & $26,787,343$ & $44,852,583$ & $33,647,592$ \\
\hline Standard error & $230,070.1$ & $6,831,255.2$ & $8,929,114.4$ & $15,857,783$ & $19,426,446.3$ \\
\hline Minimum & 0 & $1,010,058$ & $38,363,451$ & $21,943,432$ & $111,604,406$ \\
\hline Maximum & $45,368,176$ & $93,890,221$ & $111,500,127$ & $157,598,722$ & $172,870,752$ \\
\hline Amount & $1,004,189,201$ & $798,072,165$ & $652,007,581$ & $892,497,808$ & $402,602,418$ \\
\hline$\%$ of the total & 9.7 & 7.7 & 6.3 & 8.7 & 3.9 \\
\hline \multicolumn{6}{|c|}{ Continued from the above table } \\
\hline Indicator & Cluster 8 & Cluster 2 & Cluster 1 & Cluster 0 & Cluster 3 \\
\hline The number of banks & 2 & 1 & 1 & 1 & 0 \\
\hline$\%$ of the total & 0.3 & 0.2 & 0.2 & 0.2 & \\
\hline Mean & $305,928,966$ & $221,480,590$ & $1,492,998,210$ & $4,226,267,488$ & \\
\hline Standard deviation & $8,029,637$ & \multirow[t]{2}{*}{0} & \multirow[t]{2}{*}{0} & \multirow[t]{2}{*}{0} & \\
\hline Standard error & $5,677,810.5$ & & & & \\
\hline Minimum & $300,251,155$ & \multirow[t]{3}{*}{$221,480,590$} & \multirow[t]{3}{*}{$1,492,998,210$} & \multirow[t]{3}{*}{$4,226,267,488$} & \\
\hline Maximum & $311,606,776$ & & & & \\
\hline Amount & $611,857,931$ & & & & \\
\hline$\%$ of the total & 5.9 & 2.1 & 14.5 & 41 & \\
\hline
\end{tabular}

Source: Authoring

Please cite this article as: Lomakin N.I., Femelidi Yu.V.A Study of the Market Share of Loan Portfolio Through a Neural Network.

Digest Finance, 2018, vol. 23, iss. 2, pp. 230-240.

https://doi.org/10.24891/df.23.2.230 
Figure 1

The grouping of banks by asset and credit portfolio value in 2015-2016, thousand RUB

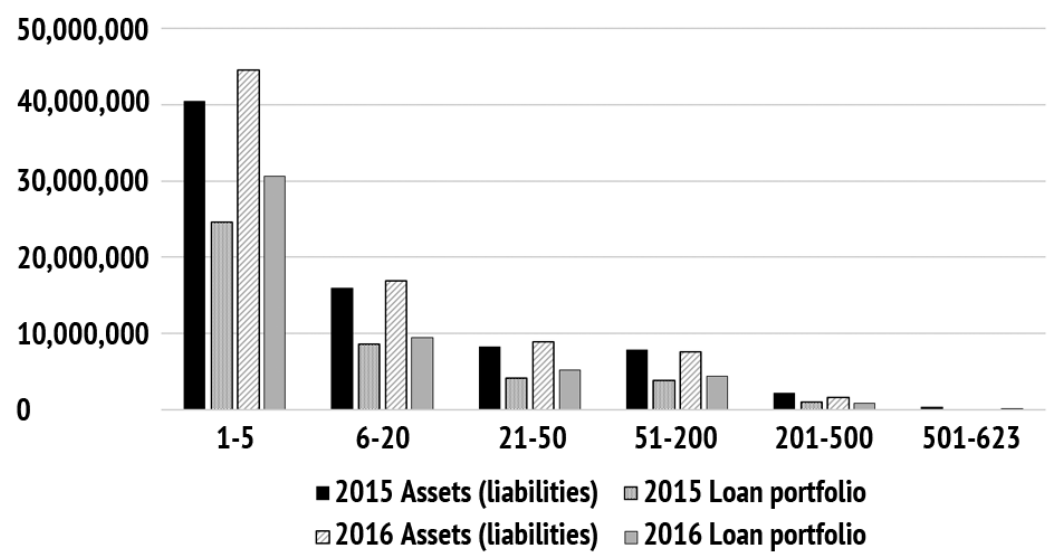

Source:The Bank of Russia data

Figure 2

Changes in assets and credit portfolio values of banks for 2015-2016, percentage point

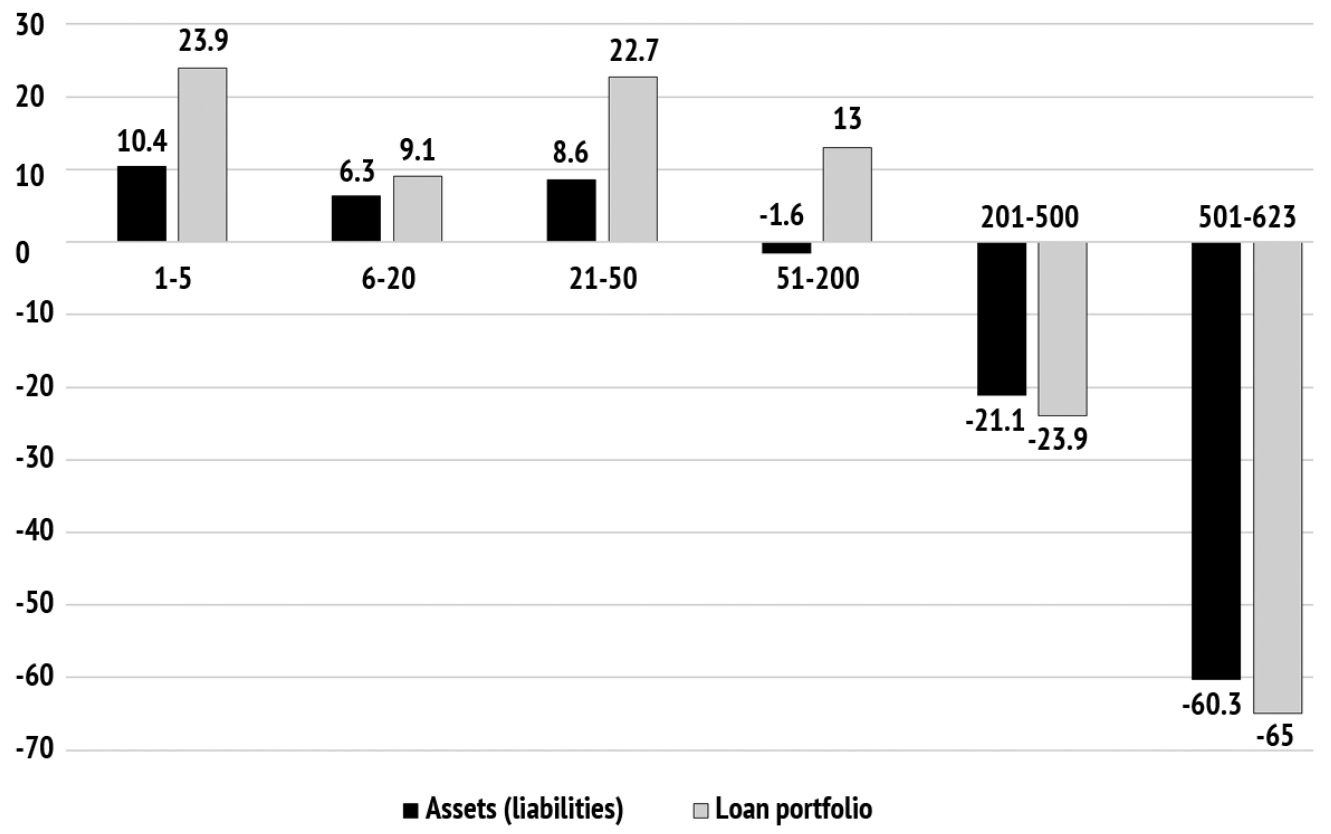

Source:The Bank of Russia data 


\section{Figure 3}

Mathematical properties of the Kohonen self-organizing map by bank: a fragment, computer visualization

\begin{tabular}{|c|c|c|c|c|c|c|c|c|c|c|c|c|}
\hline Наименвание & $\begin{array}{l}\text { 7ортфель } \\
\text { 01/08/16 }\end{array}$ & $\begin{array}{c}\text { Доля } \\
\text { рынка, } \\
\%\end{array}$ & $\begin{array}{c}\text { Портфель } \\
01 / 08 / 15 \text { r. } \\
\text { p. }\end{array}$ & $\begin{array}{c}\text { Доля } \\
\text { рынка, } \\
\%\end{array}$ & $\begin{array}{c}\text { Изменение } \\
{[+, j]}\end{array}$ & $\begin{array}{c}\text { Изменение } \\
{[\%]}\end{array}$ & $\begin{array}{l}\text { Изменение } \\
\text { (\%__UUT }\end{array}$ & $\begin{array}{l}\text { Номере } \\
\text { ячейкц }\end{array}$ & $\begin{array}{l}\text { Расстояние до центра } \\
\text { ячейки }\end{array}$ & $\begin{array}{l}\text { Номер } \\
\text { : ластер: }\end{array}$ & $\begin{array}{l}\text { Расстояние до } \\
\text { центра кластера }\end{array}$ & Изменение (\%)_ERR \\
\hline СБЕРБАНК РОССИИ & 4226267488 & 41,0183 & 4069443070 & 37.9129 & 156824418 & 3,85 & 3.85 & 31 & $7,02985357939986 \mathrm{E} \cdot 7$ & & 0,0877995946116151 & \\
\hline BTE 24 & 1492998210 & 14,4904 & 1350117517 & 12,5783 & 142880693 & 10,58 & 10,58 & 46 & $4,59144356642152 E-7$ & 1 & 0,192517665116362 & \\
\hline РОССЕЛЬХХО ЗБАНК & 311606776 & 3,0243 & 269407531 & 2,5099 & 42199245 & 15,66 & 15,66 & 93 & $5,66418554852841 \mathrm{E}-5$ & 8 & 0,0688997163405672 & \\
\hline ГАЗПРОМБАНК & 300251155 & 2,9141 & 285793233 & 2,6626 & 14457922 & 5,06 & 5,06 & 79 & 3.25108268613597E-5 & & 0,0353065004937919 & \\
\hline BTE & 221480590 & 2,1496 & 180835 & 0.0017 & 221299755 & 122376.62 & 122376,62 & 13 & $4,39574743148136 \mathrm{E} \cdot 7$ & 2 & 0,113612135331791 & \\
\hline РАЙФФАЙЗЕНБАНК & 172870752 & 1,6778 & 186517033 & 1.7377 & .13646281 & $.7,32$ & $.7,32$ & 111 & $2,07997287522022 E-5$ & & 0.0139434659828952 & \\
\hline POCEAHK & 157598722 & 1,5296 & 204759286 & 1,9076 & -47160564 & $.23,03$ & $.22,735$ & 191 & 0.00847598674880482 & 9 & 0,0584664914609622 & $5,80146460296017 \mathrm{E} \cdot 12$ \\
\hline ХКФ БАНK & 148162254 & 1.438 & 191038528 & 1,7798 & .42876274 & $.22,44$ & $\cdot 22,735$ & 191 & 0,00847644380845961 & 9 & 0,0584664914609622 & $5,80146460296004 E-12$ \\
\hline РУССКИЙ СТАНДАРТ & 147738200 & 1,4339 & 184298046 & 1,717 & -36559846 & $-19,84$ & $-20,8433333333333$ & 190 & 0,0154245296541131 & & 0,0149074964462381 & $6,71095144425662 \mathrm{E}-11$ \\
\hline ВОстОчнЫЙ & 125079325 & 1,214 & 156737580 & 1.4602 & .31658255 & $.20,2$ & $\cdot 20.8433333333333$ & 190 & 0.00707046796455122 & 9 & 0.0149074964462381 & $2,75908908673321 \mathrm{E}-11$ \\
\hline ЮНИКРЕДИТ БАНК & 118127260 & 1.1465 & 133022187 & 1.2393 & -14894927 & $.11,2$ & $.12,025$ & 126 & 0.00321491819139415 & & 0,0283283404110597 & 4.53734196540042E-11 \\
\hline МОСКОВСКИЙ КРЕДИТНЫЙ БАНК & 111604406 & 1,0832 & 128055286 & 1,193 & .16450880 & $\cdot 12,85$ & $\cdot 12,025$ & 126 & 0.00321442557541859 & 7 & 0,0283283404110597 & 4.53734196540044E-11 \\
\hline ДЕЛЬТАКРЕДИТ & 1500127 & 1.0822 & 98611182 & 0.9187 & & & 13,455 & 92 & 5153867 & 4 & & $9,88132250242759 \mathrm{E}-12$ \\
\hline ХАНТЫ-МАНСИЙСКИЙ БАНК ОТКРЫТИЕ & 111175085 & 1,079 & 143435666 & 1,3363 & .32260581 & $.22,49$ & $\cdot 20,8433333333333$ & 190 & 0,0095701400773315 & 9 & 0,0149074964462381 & $1,80761111538571 \mathrm{E}-10$ \\
\hline ТИНЬКОФФ БАНК & 109940200 & 1.067 & 96576929 & 0.8998 & 13363271 & 13,84 & 13,455 & 92 & 0.000983251392769392 & & 0.0148145206288864 & $9.88132250242759 E-12$ \\
\hline TPACT & 100515258 & 0,9756 & 122201553 & 1,1385 & .21686295 & $\cdot 17,75$ & $-17,75$ & 174 & $1,24276504731818 \mathrm{E} \cdot 5$ & 9 & 0,0354289220990866 & \\
\hline СЕТЕЛЕМ БАНК & 93890221 & 0.9113 & 95844178 & 0.8929 & 3957 & $-2,04$ & $-1,765$ & 124 & 368393322274 & & 0,0282428576671089 & $5,04149107266714 E-12$ \\
\hline РУСФИН & 80397 & 0,884 & 84533 & 036 & & $-6,1$ & $-6,1$ & 125 & $58 E \cdot 6$ & 6 & & \\
\hline ПРОМСВЯЗЬБАНК & 759579 & 0.8615 & 199823 & 0.8394 & 40244 & $-1,49$ & $-1,765$ & 124 & 4809863578811 & & 0,0282428578 & $5.04149107266715 E-12$ \\
\hline ПОЧТА БАНК & 129557 & 0.8194 & 34408 & 0.53 & 26795149 & 46,49 & 46,49 & 44 & $1.51182202479668 \mathrm{E}-5$ & 4 & 0.048414538491537 & \\
\hline СВЯЗЬ-БАНК & 187967 & 0.8074 & 69578306 & 0.6482 & 13609661 & 19,56 & 19,56 & 76 & $1.54285212518875 E-5$ & & 0.00144681288123071 & \\
\hline ОТП БАНК & 85532 & 0.7792 & 112653257 & & .3236 & 28.73 & $-44,085$ & 159 & 68122 & & 0,0258 & $1,57178542173414 \mathrm{E}-8$ \\
\hline РЕНЕССАНС КРЕДИТ & 79226263 & 0.7689 & 56114 & 0,7337 & 149 & 0.6 & $-1,765$ & 124 & 34731 & 6 & 0,02824 & $3.72868679734462 E-10$ \\
\hline CKE-EAHK & & & & & & & 9,67 & 91 & & & & \\
\hline СОВКОМБАНК & 61213574 & 0.5941 & 61890472 & 0.5766 & .676898 & $-1,09$ & $-1,5$ & 123 & 0.00338238852405201 & 6 & 0.0222464802588504 & $1,12062763545831 \mathrm{E} \cdot 11$ \\
\hline БАНК "САHКТ-ПЕТЕРБУРГ" & 59307778 & 0.5756 & 52146469 & 0.4858 & 7161309 & & 13,73 & 75 & $9,2076265615989 E \cdot 6$ & & 0,0263775278967127 & \\
\hline АЗИАТСКО-ТИХООКЕАНСКИЙ БАНК & 50317596 & 0,4884 & 56766344 & 0.5289 & .6448748 & $-11,36$ & $-11,36$ & 156 & 8,3203505 & & 0504 & \\
\hline BO3POK. & 2509 & 0,4838 & 56585 & 0,3564 & 11595924 & & 33,72 & 26 & 7822 & 4 & 0,01681494 & $7.751796673333 E-10$ \\
\hline КРЕДИТ ЕВРОПА БАНК & 49114974 & 0,4767 & 63054874 & 0.5874 & -13939900 & $.22,11$ & $.22,11$ & 189 & $6.61472857773048 E-6$ & 6 & 0,0272604109839578 & \\
\hline СИТИБАНК & 47152798 & 0,4576 & 48069773 & 0,4478 & -916975 & $-1,91$ & $-1,5$ & 123 & 0.00340129905186375 & 6 & 0,0222464802588504 & $1,12062763545831 \mathrm{E}-11$ \\
\hline АБССЛЮТ БАНК & 46058877 & 0.447 & & & & 37,13 & 33.72 & 26 & 0.00192245439955206 & 4 & & $7,75179667333302 E-10$ \\
\hline AK EAPC & 45368176 & 0.4403 & 42571197 & 0,3966 & 2796979 & 6.57 & 6.57 & 107 & $2,782608534985 \mathrm{E} \cdot 6$ & 5 & 0,0209341906804771 & \\
\hline
\end{tabular}

Source:Authoring

Figure 4

Adjusting the weights of the wining neuron and its neighbors

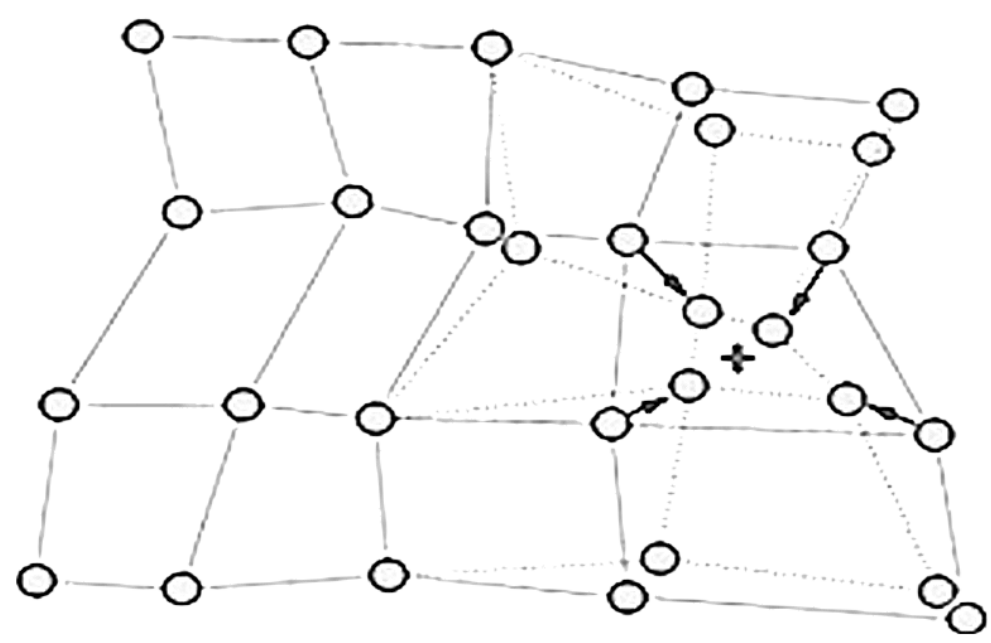

Source:Authoring

Please cite this article as: Lomakin N.I., Femelidi Yu.V. A Study of the Market Share of Loan Portfolio Through a Neural Network.

Digest Finance, 2018, vol. 23, iss. 2, pp. 230-240. 


\section{Figure 5}

Changes in the composition and structure of credit portfolios of commercial banks in the neural network of the Kohonen self-organizing map: computer visualization

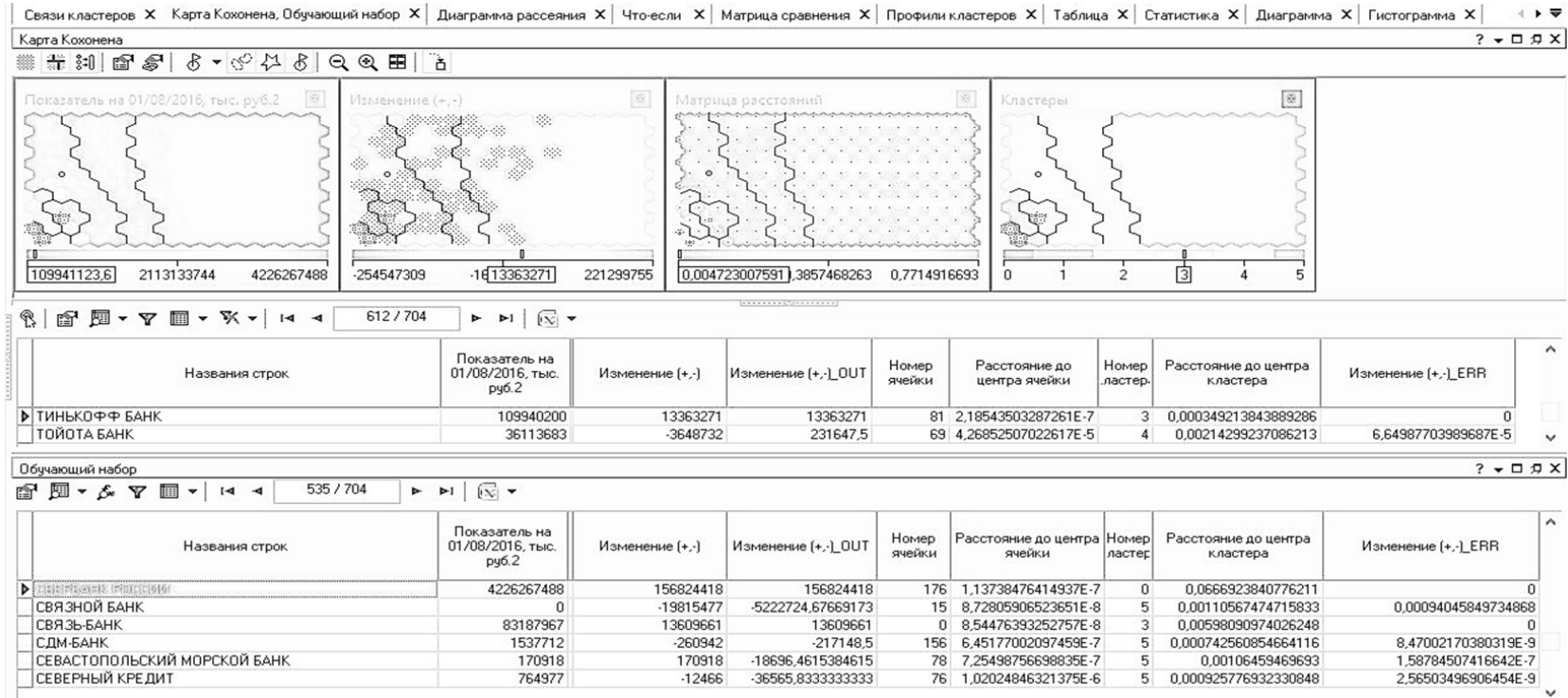

Source:Authoring

\section{Figure 6}

Cluster profiles: computer visualization

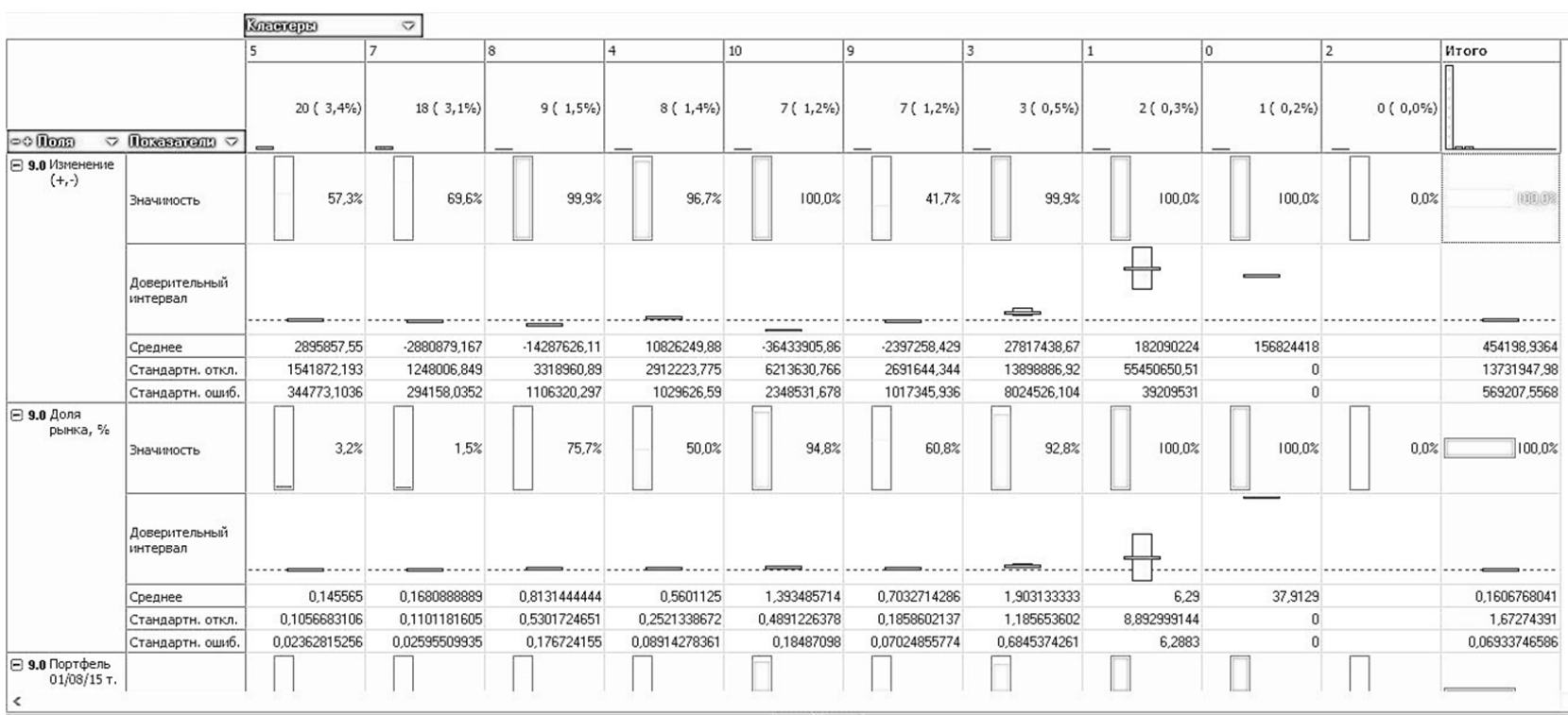

Source: Authoring

Please cite this article as: Lomakin N.I., Femelidi Yu.V.A Study of the Market Share of Loan Portfolio Through a Neural Network. 
Figure 7

Distribution of risk (standard deviation) and value of portfolio share (right-hand scale) by cluster of the self-organizing map

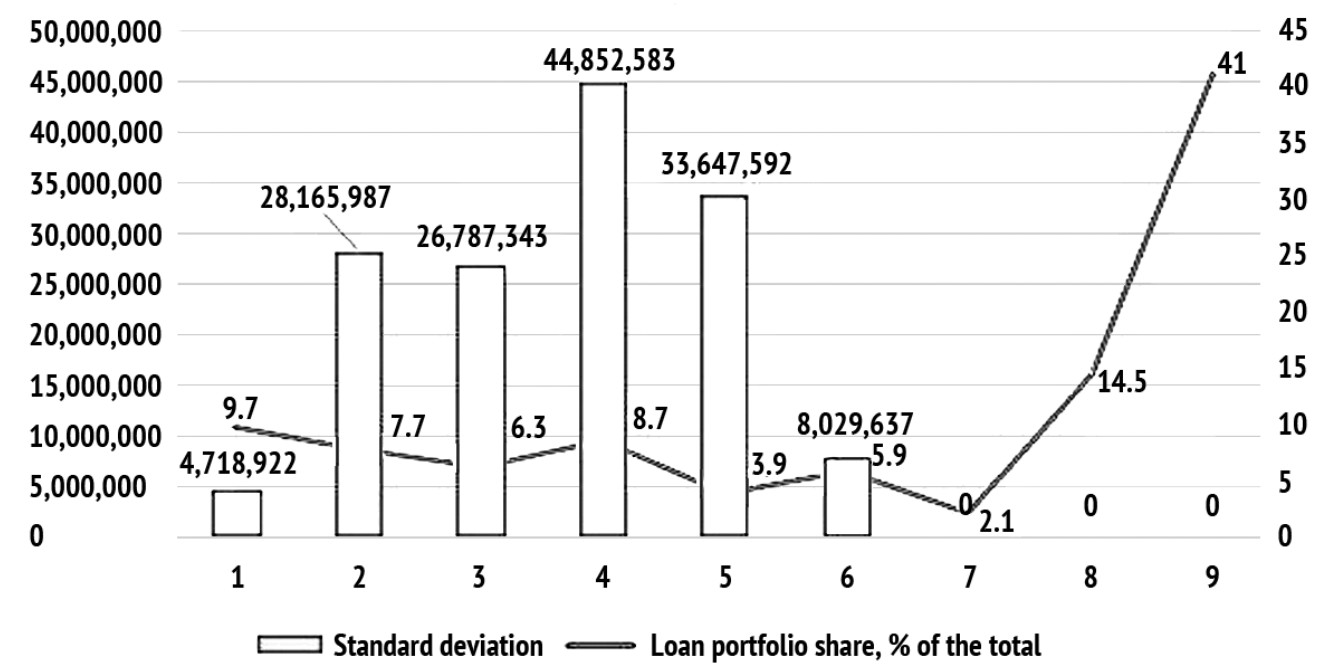

Source:Authoring

\section{References}

1. Belyaev V.I., Krotova M.V. [Marketing strategies of the development of enterprises in the service sector: Methods of formation and justification]. Vestnik Altaiskogo gosudarstvennogo agrarnogo universiteta $=$ Bulletin of Altai State Agricultural University, 2015, no. 1, pp. 156-159. URL: http://www.asau.ru/vestnik/2015/1/156-159.pdf (In Russ.)

2. Kukhlev B.E. [Application of Porter's Five Forces Framework and SWOT analysis for planning of an agrarian enterprise's activities: Evidence from OAO Del'ta-Agro]. Regional'naya ekonomika: teoriya i praktika= Regional Economics: Theory and Practice, 2012, no. 5, pp. 52-56.

URL: https://cyberleninka.ru/article/v/primenenie-analiza-pyati-sil-m-portera-i-swot-analiza-dlya-planirovaniyadeyatelnosti-agrarnogo-predpriyatiya-na-primere-oao-delta-agro (In Russ.)

3. Balyberdin V.A., Belevtsev A.M., Benderskii G.P. Prikladnye metody otsenki i vybora reshenii v strategicheskikh zadachakh innovatsionnogo menedzhmenta [Applied methods of assessment and decision making in strategic problems of innovation management]. Moscow, Dashkov i Ko Publ., 2014, 240 p.

4. Grebenik T.V. [Modern features of effective management of loan portfolio quality]. Naukovedenie, 2014, no. 5, p. 145. (In Russ.) URL: https://naukovedenie.ru/PDF/116EVN514.pdf

5. Grishankin A.I., Lomakin N.I. [Financial risk management algorithm based business method of fuzzy]. V mire nauchnykh otkrytii = In the World of Scientific Discoveries, 2013, no. 12, pp. 115-140. (In Russ.)

6. Yakovenko S.N., Markelova A.S. [Optimization of quality assessment and management of the loan portfolio of commercial bank]. Ekonomika i predprinimatel'stvo = Journal of Economy and Entrepreneurship, 2015, no. 6-2, pp. 596-601. (In Russ.)

7. Miranda M.J., Gonzalez-Vega C. Systemic Risk, Index Insurance, and Optimal Management of Agricultural Loan Portfolios in Developing Countries. American Journal of Agricultural Economics, 2010, vol. 93, iss. 2, pp. $399-406$. URL: https://doi.org/10.1093/ajae/aaq109

Please cite this article as: Lomakin N.I., Femelidi Yu.V.A Study of the Market Share of Loan Portfolio Through a Neural Network. 
8. Marshall J., Evans N., Currie A. et al. Portfolio Management Shores Up Loan Books. Euromoney, 2002, no. 7, pp. 122-124.

9. Lucas A., Klaassen P., Spreij P., Straetmans S. An Analytic Approach to Credit Risk of Large Corporate Bond and Loan Portfolios. Journal of Banking \& Finance, 2001, vol. 25, iss. 9, pp. 1635-1664.

URL: https://doi.org/10.1016/S0378-4266(00)00147-3

10. Kadyrov A.N. [A methodology for determining the risk category of the borrower to manage the risk level of bank's loan portfolio]. Finansy i kredit = Finance and Credit, 2002, no. 7, pp. 46-51.

URL: https://cyberleninka.ru/article/v/metodika-opredeleniya-kategorii-riska-zaemschika-dlya-upravleniyaurovnem-riska-kreditnogo-portfelya-banka (In Russ.)

11. Maksimova O.N., Zagornaya T.O. et al. Nauchnye otvety na vyzovy sovremennosti: ekonomika [Scientific answers to the challenges of modernity: economics: a monograph. In 2 volumes]. Odessa, Kuprienko S.V. Publ., 2016, vol. 2, $185 \mathrm{p}$.

12. Knight F.H. Risk, neopredelennost' i pribyl' [Risk, Uncertainty, and Profit]. Moscow, Delo Publ., 2003,360 p.

13. Van Eyden R.J. The Application of Neural Networks in the Forecasting of Share Prices. National Research Foundation: Nexus-Current \& Completed Projects. URL: http://nrfnexus.nrf.ac.za/ handle/20.500.11892/177210

14. Lomakin N.I. Innovatsii v bankovskoi sfere - faktor povysheniya konkurentosposobnosti s pozitsii steikkholderskoi teorii firmy: monografiya [Innovation in the banking sector is a factor for increasing the competitiveness from the standpoint of stakeholder theory of firm: a monograph]. Saarbrucken, Germany, LAP LAMBERT Academic Publishing, 2015, 197 p.

\section{Conflict-of-interest notification}

We, the authors of this article, bindingly and explicitly declare of the partial and total lack of actual or potential conflict of interest with any other third party whatsoever, which may arise as a result of the publication of this article. This statement relates to the study, data collection and interpretation, writing and preparation of the article, and the decision to submit the manuscript for publication.

Please cite this article as: Lomakin N.I., Femelidi Yu.V.A Study of the Market Share of Loan Portfolio Through a Neural Network. 